\title{
New stability indicating RP-HPLC-PDA method for determination of mifepristone in bulk and tablet formulation
}

\author{
Mohammad Mojeeb Gulzar Khan 1*, Mohammad Faizan Saadique Deshmukh', Sandip Dinkar Firke1, \\ Abdul Talib Abdul Wahab', Mohan Ganpatrao Kalaskar² and Atul Arun Shirkhedkar ${ }^{1}$
}

\begin{abstract}
Background: Mifepristone is progestational and glucocorticoid hormone antagonist. The objective of this study is to develop simple and economical stability indicating RP-HPLC method for the determination of mifepristone in bulk and tablet formulation.

Result: The chromatographic separation was achieved on Qualisil BDS C8 column with mobile phase containing of mixture of Buffer (Potassium dihydrogen ortho phosphate, pH to 3.0 with ortho phosphoric acid) and Organic Solvent (Acetonitrile) 60:40 v/v pumped at flow rate $0.6 \mathrm{~mL} \mathrm{~min}^{-1}$. The detection of elute was performed using PDA detector at $305 \mathrm{~nm}$. Mifepristone was eluted at $8.67 \mathrm{~min}$. According to international conference on harmonization Q2(R1) guideline, method was validated and shows satisfactory results for accuracy, precision, linearity, ruggedness, robustness, detection limit, quantitation limit. The method indicated to be linear in the series of concentration 3-18 $\mathrm{g} \mathrm{mL}^{-1}$, and correlation coefficient was 0.9997. In acidic, basic, oxidative, thermal, photolytic forced degradation conditions, the peak of degradation product was clearly and well separated from drug peak without any interference in quantitative analysis. This represents stability indicating nature of established method.
\end{abstract}

Conclusion: The established RP-HPLC method is simple, accurate, specific, precise, robust, rugged, sensitive, and economical in nature which can be utilized for routine analysis of mifepristone in bulk and pharmaceutical formulation.

Keywords: Mifepristone, Stability indicating RP-HPLC method, Forced degradation studies

\section{Background}

Mifepristone is also known as RU-486 and chemically 17ß-Hydroxy-11ß-(4-dimethylamino) phenyl-17-(1-propynyl)-4, 9-estradien-3-one (Fig. 1). It is progestational and glucocorticoid hormone antagonist. As a glucocorticoid receptor antagonist, the drug has been used to treat hypercortisolism in patients with nonpituitary Cushing syndrome. The anti-progestational activity of mifepristone results from competitive interaction with

\footnotetext{
*Correspondence: mujeebgulzar@gmail.com

${ }^{1}$ Department of Pharmaceutical Chemistry, R.C. Patel Institute of Pharmaceutical Education and Research, Shirpur, Dist. Dhule, MS 425 405, India

Full list of author information is available at the end of the article
}

progesterone at progesterone-receptor sites. Based on studies with various oral doses in several animal species, the compound inhibits the activity of endogenous or exogenous progesterone which results in the termination of pregnancy [1-4]. Detailed literature survey revealed that HPLC [5] simultaneous determination of mifepristone with misoprostol, LC-MS [6-12], and HPTLC [13] methods has been reported for determination of mifepristone in bulk and biological fluids. UV spectrophotometric methods $[14,15]$ have been reported. As far as up to our knowledge till date, no stability indicating simple, reliable RP-HPLC method has been established for determination of mifepristone in bulk and pharmaceutical formulation. So, the goal of research work is to 


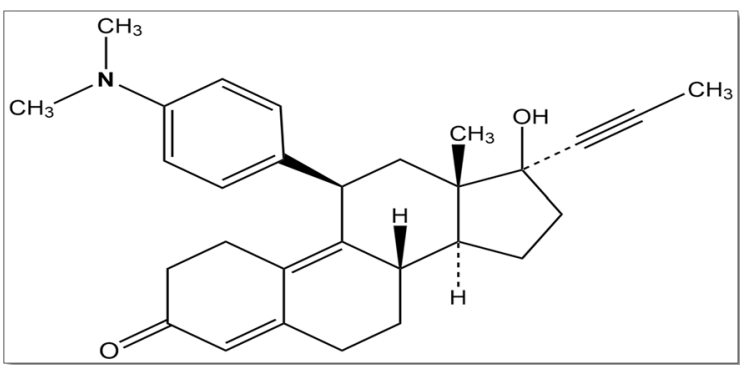

Fig. 1 Chemical structure of mifepristone

establish simple, accurate, rapid, specific, reproducible, and economical stability indicating RP-HPLC method for determination of mifepristone in bulk and pharmaceutical formulation. The established method was further validated according to ICH guidelines Q2 (R1) [16, 17].

\section{Method}

\section{Pure sample}

Mifepristone purity of $99.9 \%$ was received from Teva pharmaceutical, Mumbai, India, as a gift sample.

\section{Formulation}

$200 \mathrm{mg}$ tablet formulation of mifepristone manufactured by Zee laboratories LTD under the brand name RELEZED was used.

\section{Chemicals and reagents}

HPLC grade solvents Methanol (Rankem, avantor performance materials India Ltd. Thane, India), Acetonitrile (Merck specialities Pvt. Ltd. Worli, Mumbai, India), orthophosphoric acid (Lobachemie Pvt. Ltd. Mumbai, India), Potassium dihydrogen orthophosphate (Lobachemie Pvt. Ltd. Mumbai, India), sodium hydroxide (Lobachemie Pvt. Ltd. Mumbai, India), hydrochloric acid (RFCL Ltd. New Delhi, India), and Hydrogen peroxide (Merck life science Pvt. Ltd. Worli, Mumbai, India) were purchased for experimental work. Double distilled water was obtained from distillation process. The marketed formulation (RELEZED $200 \mathrm{mg}$ ) was purchased from local market for scientific study purpose.

\section{RP-HPLC instrumentation and chromatographic condition} Analysis of mifepristone was done on chromatographic system high-performance liquid chromatography UFLCLC 20 AD (Shimadzu Corporation, Japan) consisting of LC-20 AD binary solvent delivery system (pump), SPDM20A diode array detector and CTO 10 AS vp; column oven, a Rheodyne injector with $20 \mu \mathrm{L}$ loops and a Hamilton syringe $(100 \mu \mathrm{L})$. The chromatographic separations were achieved on a Qualisil BDS C8 column
(250 $\mathrm{mm} \times 4.6$ mmi.d. $5 \mu \mathrm{m})$ using mobile phase consisting of acetonitrile: $10 \mathrm{mM}$ potassium dihydrogen orthophosphate 40:60 v/v ratio, $\mathrm{pH}$ was adjusted to 3.0 with orthophosphoric acid. Before analysis, mobile phase was filtered through $0.2 \mu \mathrm{m}$ membrane filter and degassing was performed by ultrasonicator (ENERTECH Electronics Pvt. Ltd., India). Whole experiment was carried out at $32{ }^{\circ} \mathrm{C}$, and flow rate was kept at $0.6 \mathrm{~mL} \mathrm{~min}{ }^{-1}$. The sample solution of $20 \mu \mathrm{L}$ was manually injected into column using Hamilton syringe. The eluted analyte was detected at $305 \mathrm{~nm}$. Data gathering and study were carried out by LC-Solution data processor software (Shimadzu Corporation, Japan). For reflux propose, Radleys Carousel 6 plus reaction station (England) apparatus was used.

\section{Methodology}

\section{Selection of wavelength}

From standard stock solution, $1 \mathrm{~mL}$ of solution was withdrawn and transferred into volumetric flask having capacity $10 \mathrm{~mL}$ and volume was make up by methanol up to the mark and scanned in UV region from 200 and $400 \mathrm{~nm}$ using UV-visible double beam spectrophotometer (Model-2450, SHIMADZU, Japan) with data processing software UV probe v2.21 and from the acquired UV spectra a wavelength of $305 \mathrm{~nm}$ was selected as ideal wavelength used as PDA detector wavelength in RPHPLC analysis.

\section{Preparation of mobile phase}

Acetonitrile and $10 \mathrm{mM}$ potassium dihydrogen orthophosphate in the ratio of 40:60 v/v were used as a mobile phase. $\mathrm{pH}$ of mobile phase was adjusted to 3.0 by orthophosphoric acid. Before analysis, mobile phase was filtered through $0.2 \mu \mathrm{m}$ membrane filter and degassing was performed by ultrasonicator.

\section{Preparation of standard solution}

Standard stock solution was prepared by dissolving accurately weighed $10 \mathrm{mg}$ mifepristone in $100 \mathrm{~mL}$ volumetric flask containing methanol to obtain concentration of $100 \mu \mathrm{gL}^{-1}$.

\section{Method validation}

The established chromatographic methods were absolutely validated followed by ICH guidelines Q2 (R1) and Q1A (R2) for the validation of analytical methods and Stability testing of new substance and product, respectively $[16,17]$.

\section{Linearity}

From standard stock solution, six sets of series of concentration ranging from 03 to $18 \mu \mathrm{g} \mathrm{mL} \mathrm{m}^{-1}$ were obtained by diluted $0.3-1.8 \mathrm{~mL}$ concentration from $100 \mu \mathrm{g} \mathrm{mL}{ }^{-1}$ with 
methanol in $10 \mathrm{~mL}$ volumetric flask and analyzed it. Linear curve equation was made by plotting the peak area versus drug concentration.

\section{Precision}

Precision studies were carried out by using drug standard solution in concentration taken in the calibration range. The precision of the developed method by means of intra-day variation (\% RSD) was observed by analyzing standard drug solution in three sets of concentration of Mifepristone, i.e., $6 \mu \mathrm{g} \mathrm{mL}{ }^{-1}, 9 \mu \mathrm{g} \mathrm{mL}{ }^{-1}$, and $12 \mu \mathrm{g} \mathrm{mL}^{-1}$ on same day. Inter-day precision (\% RSD) was studied by analyzing the drug solution in same concentration used for intraday three times on three days in one week period.

Repeatability studies were performed by analyzing six replicates of same concentrations $\left(9 \mu \mathrm{g} \mathrm{mL}^{-1}\right)$ on same day.

\section{Accuracy}

Accuracy study of established method was determined by percent recovery studies. To the pre-tested sample, standards drug concentrations were added at three different points $(80 \%, 100 \%$, and $120 \%)$. At each level of the amount, three estimations were evaluated and the percentage recovery and percentage mean recovery were calculated.

\section{Ruggedness}

Ruggedness study of established method was estimated by analysis of same aliquots $9 \mu \mathrm{g} \mathrm{mL}^{-1}$ of pure mifepristone at same operational and environmental conditions by two different analysts.

\section{Detection and quantitation limit}

Detection limit and quantification limit were determined by analysis of lower concentration of the linear range of the linear curve equation which were calculated using formulae "L.O.D $=3.3 \times \mathrm{ASD} / \mathrm{M}$ " and "L.O.Q $=10 \times \mathrm{ASD} / \mathrm{M}$, where "ASD" is average standard deviation of the peak areas of the mifepristone $(n=3)$, taken as a measure of noise, and " $\mathrm{M}$ " is the slope related to linear curve equation.

\section{Analysis of tablet formulation}

Twenty tablets of mifepristone (RELEZED having label claim $200 \mathrm{mg}$ ) were accurately weighed, average weight determined then transferred to a clean waterless mortar and crushed into fine powder by pestle. Above fine powder equivalent to $10 \mathrm{mg}$ mifepristone was transferred to volumetric flask having capacity $100 \mathrm{~mL}$ containing $70 \mathrm{~mL}$ of methanol; this mixture subjected to sonication for $10 \mathrm{~min}$ after that volume was made by methanol up to the mark and filtered through $0.45 \mu \mathrm{m}$ Whatman filter paper its give $100 \mu \mathrm{g} \mathrm{mL} \mathrm{m}^{-1}$ concentration. From this stock solution, sets of same concentration (i.e., $1.5 \mathrm{~mL}$ ) separately transferred to volumetric flask having capacity $10 \mathrm{~mL}$ and volume was made by methanol up to the mark to get final concentration of $15 \mu \mathrm{g} \mathrm{mL}^{-1}$ and this solution was injected into column with Hamilton syringe. The peak area recorded and drug concentration in sample were estimated from linear curve equation.

\section{System suitability}

System suitability study was done to confirm that the HPLC system is working correctly and can provide accurate and precise results. It was evaluated by injecting $10 \mu \mathrm{g} \mathrm{mL} \mathrm{m}^{-1}$ solution of mifepristone six times. Solution of concentration of $10 \mu \mathrm{g} \mathrm{mL} \mathrm{m}^{-1}$ of mifepristone was prepared by pipette out $1.0 \mathrm{~mL}$ solution from the standard stock solution into volumetric flask having capacity up to $10 \mathrm{~mL}$ and diluted with methanol up to the mark. The following parameters of system suitability like theoretical plates, tailing factor, retention time and capacity factor were evaluated.

\section{Robustness}

Robustness study was performed for established RPHPLC method by change in the chromatographic conditions, To study the impact of flow rate on the resolution, the flow rate was changed by 0.2 units, i.e., 0.4 and $0.8 \mathrm{~mL} \mathrm{~min}{ }^{-1}$ from the actual flow rate $0.6 \mathrm{~mL} \mathrm{~min}{ }^{-1}$. The impact of temperature of column on resolution was studied at $30{ }^{\circ} \mathrm{C}$ and $34{ }^{\circ} \mathrm{C}$ instead of $32{ }^{\circ} \mathrm{C}$. The impact of change in the composition of mobile phase was observed by changing the $\%$ of acetonitrile in gradient by $2 \%$. The impact of $\mathrm{pH}$ was studied by changing $\mathrm{pH}$ by 0.2 units from the actual value 3.0 keeping remaining method conditions were kept constant.

\section{Forced degradation studies}

Forced degradation studies were carried out on mifepristone under several conditions as per ICH guidelines Q1A (R2) and Q1 B.

\section{Acidic condition}

For acid degradation study, $10 \mathrm{mg}$ of pure mifepristone transferred in $10 \mathrm{~mL}$ volumetric flask and dissolved in $10 \mathrm{~mL} 0.1 \mathrm{~N}$ methanolic $\mathrm{HCl}$ and refluxed at $70{ }^{\circ} \mathrm{C}$ for $3 \mathrm{~h} .0 .1 \mathrm{~mL}$ solution was taken out, and methanol is used for the dilution of resulting solution.

\section{Basic condition}

Base degradation study was carried out by taking $10 \mathrm{mg}$ of pure mifepristone transferred in $10 \mathrm{~mL}$ volumetric flask and dissolved in $10 \mathrm{~mL} 0.1 \mathrm{~N}$ methanolic $\mathrm{NaOH}$ and 
refluxed at $70{ }^{\circ} \mathrm{C}$ for $3 \mathrm{~h} .0 .1 \mathrm{~mL}$ solution was taken, and methanol is used for the dilution of resulting solution.

\section{Oxidative condition}

$10 \mathrm{mg}$ of pure mifepristone was dissolved in $10 \mathrm{~mL} 12 \%$ methanolic hydrogen peroxide solution, up to the mark. This solution is kept for $24 \mathrm{~h}$ in dark place to avoid the degradation effect of light. Methanol is used for the dilution of resulting solution.

\section{Dry heat condition}

Dry heat degradation study was performed by taking $10 \mathrm{mg}$ of pure mifepristone in a clean and dry petri dish and kept in hot air oven at $80^{\circ} \mathrm{C}$ for $8 \mathrm{~h}$. After completion of stipulated time, resulting dilution was made by using methanol.

\section{Wet heat condition}

The $10 \mathrm{mg}$ mifepristone was taken into a $10 \mathrm{~mL}$ volumetric flask, and volume make-up was done by methanol kept in a hot air oven at $80^{\circ} \mathrm{C}$ for $8 \mathrm{~h}$. After an 8 -h, volumetric flask was removed from the hot air oven, $0.1 \mathrm{~mL}$ of concentration was withdrawn and transferred to a volumetric flask having a capacity of $10 \mathrm{~mL}$. Volume was made by methanol up to the mark.

\section{Photolytic condition}

Photolytic degradation study was performed exposing sample for 7 days to sun light. The previously exposed sample was correctly weighed and diluted with methanol to get desired resulting solution.

\section{Results}

\section{HPLC method development}

The proposed RP-HPLC method was optimized with a vision to establish a suitable, easy, and economical stability indicating HPLC method. Optimization of mobile phase was attempted by using mixture of different solvent (buffers and organic solvent like ammonium acetate, potassium dihydrogen ortho phosphate, methanol, and acetonitrile) with different $\mathrm{pH}$ conditions. The different mobile phase and their proportion were tried for mobile phase optimization. The best chromatogram obtained with acetonitrile: potassium dihydrogen ortho-phosphate $(40: 60 v / v) \mathrm{pH}$ adjusted to 3.0 with ortho phosphoric acid. The established solvent system was found to have very good symmetry with retention time $(8.67 \pm 0.02)$ and sharp well-defined peak. The detection was performed by PDA detector at $305 \mathrm{~nm}$. The total run time of system was $15 \mathrm{~min}$, and a typical chromatograph of mifepristone standard and sample is shown in Fig. 2.

\section{Method validation}

\section{Linearity}

The linearity parameter was performed by established RP-HPLC method in the range of concentration 03-18 $\mu \mathrm{g} \mathrm{mL}^{-1}$. Linear regression data obtained from linear curve are shown in Table 1.

\section{Precision}

Intra-day, inter-day precision, and repeatability were studied under precision parameter. The data obtained for all precision parameter are depicted in Table 1.

\section{Accuracy}

Accuracy of proposed method was determined by recovery studies. Standard drug solution was added in pre-tested sample at three different points $80 \%, 100 \%$, $120 \%$. The results obtained are depicted in Table 1.

\section{Ruggedness}

Ruggedness study for established method was determined by six replicates of two sets obtained from homogeneous solution of pure mifepristone analyzed under same operational and environmental conditions by two different analysts. The results obtained in acceptable range in terms of \% RSD less than 2 are depicted in Table 1. The results demonstrate no statistical variances between different analyst using same operational and environmental condition, suggesting that the established RP-HPLC methods are rugged.

\section{Detection limit and quantitation limit}

$\mathrm{DL}$ and $\mathrm{QL}$ of pure mifepristone were found to be $0.15 \mu \mathrm{g} \mathrm{mL}^{-1}$ and $0.50 \mu \mathrm{g} \mathrm{mL}^{-1}$, respectively. The values of DL and QL indicate the sensitivity of established method.

\section{Analysis of tablet formulation}

The established RP-HPLC method has been effectively applied for the assay of mifepristone in bulk sample and tablet formulation. The result of assay of mifepristone was found to be in the range of $98-100 \%$ which is depicted in Table 2.

\section{Robustness}

Robustness parameter was studied by making small alterations in mobile phase proportion, flow rate, temperature, and $\mathrm{pH}$ condition $( \pm 02 \%)$, and the effect of changes on results was examined. The standard deviation and \% RSD of peak area of drug was calculated for each parameter. The results are shown in Table 1 . The $\%$ 

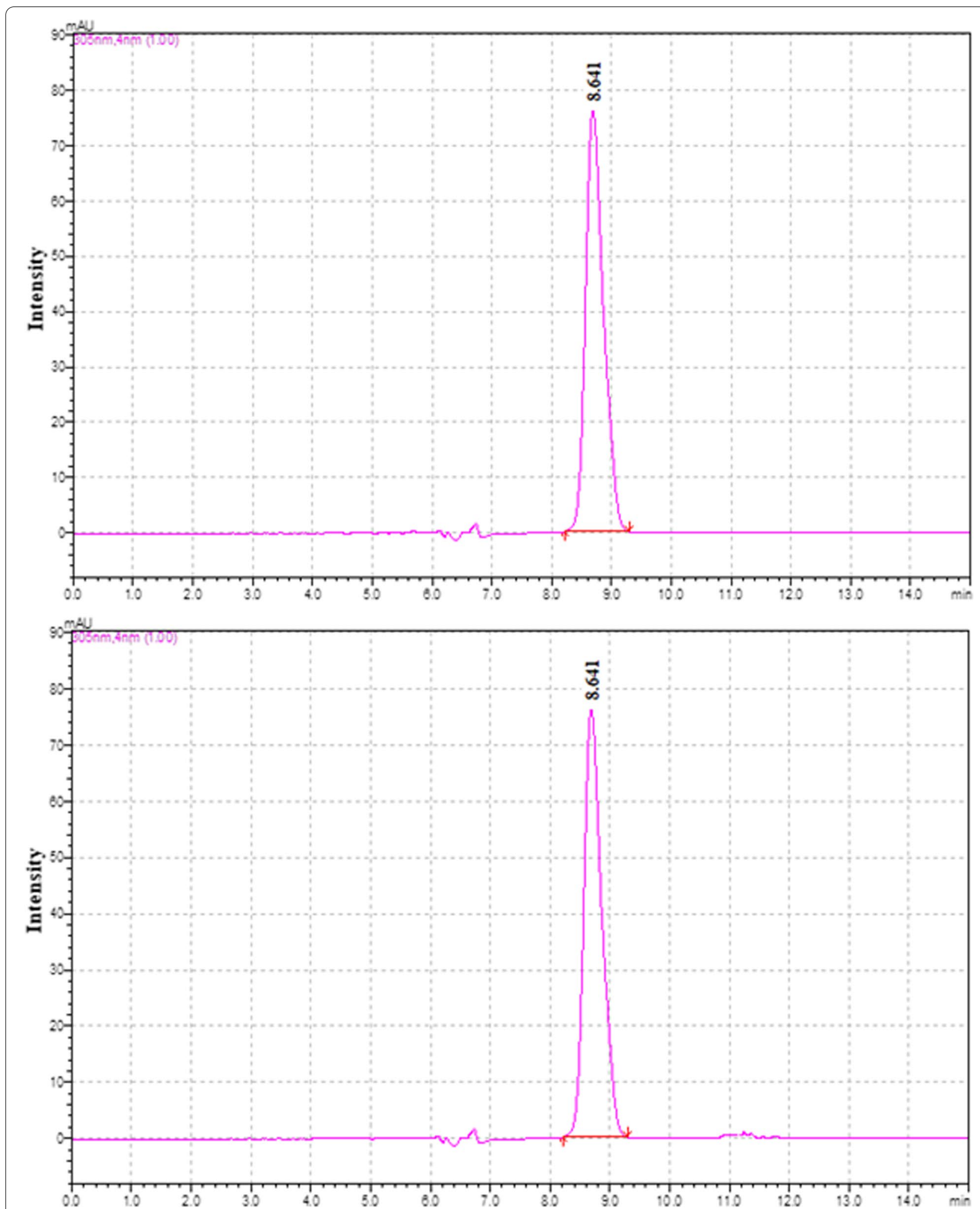

(b)

Minutes

Fig. 2 A typical chromatogram showing standard solution (a) and sample solution (b) of mifepristone 
Table 1 Results of validation parameter

\begin{tabular}{|c|c|c|c|c|}
\hline Concentration of MFP $\left(\mu \mathrm{g} \mathrm{mL}^{-1}\right)$ & $\begin{array}{l}\text { Peak area } \\
\text { Mean } \pm \text { SD }(n=6)\end{array}$ & $\begin{array}{l}\text { Amount found }\left(\mu \mathrm{g} \mathrm{mL}^{-1}\right) \\
(n=3)\end{array}$ & $\begin{array}{l}\% \text { amount found } \\
\left(\mu \mathrm{g} \mathrm{mL}^{-1}\right)(n=3)\end{array}$ & $\%$ RSD \\
\hline \multicolumn{5}{|l|}{ Linearity studies of mifepristone } \\
\hline 3 & $348,508 \pm 579.06$ & - & - & 0.17 \\
\hline 6 & $637,116 \pm 7790.85$ & - & - & 1.22 \\
\hline 9 & $950,741 \pm 3787.78$ & - & - & 0.40 \\
\hline 12 & $1,246,160 \pm 14,321.09$ & - & - & 1.15 \\
\hline 15 & $1,571,188 \pm 9559.71$ & - & - & 0.61 \\
\hline 18 & $1,885,411 \pm 12,610.39$ & - & - & 0.67 \\
\hline \multicolumn{5}{|l|}{ Precision studies of mifepristone } \\
\hline \multicolumn{5}{|l|}{ Intra-day precision } \\
\hline 6 & - & 6.00 & 99.98 & 0.11 \\
\hline 9 & - & 9.00 & 100.00 & 0.06 \\
\hline 12 & - & 11.94 & 99.48 & 0.90 \\
\hline \multicolumn{5}{|l|}{ Inter-day precision } \\
\hline 6 & - & 6.02 & 100.36 & 0.40 \\
\hline 9 & - & 9.02 & 100.24 & 0.11 \\
\hline 12 & - & 11.94 & 99.54 & 0.57 \\
\hline \multicolumn{5}{|c|}{ Precision studies [repeatability] of mifepristone } \\
\hline 9 & & 8.97 & 99.63 & \\
\hline 9 & & 9.02 & 100.19 & \\
\hline 9 & & 9.01 & 100.09 & \\
\hline 9 & & 9.00 & 100.05 & \\
\hline 9 & & 9.01 & 100.15 & \\
\hline 9 & & 9.00 & 100.03 & \\
\hline Mean $\pm S D$ & & $9.00 \pm 0.02$ & $100.02 \pm 0.20$ & \\
\hline$\%$ RSD & & 0.20 & 0.20 & \\
\hline \multicolumn{5}{|l|}{ Ruggedness studies } \\
\hline 9 (Analyst I) & & & $99.82 \pm 0.41$ & \\
\hline 9 Analyst II) & & & $99.91 \pm 0.27$ & \\
\hline Parameters & Tailing factor & Theoretical plates & $\%$ RSD & \\
\hline
\end{tabular}

Robustness studies of mifepristone

Change in $\mathrm{pH}$ of buffer

\begin{tabular}{|c|c|c|c|}
\hline 2.8 & 1.43 & 4046.3 & 0.60 \\
\hline 3.0 (Optimized condition) & 1.13 & 4097.1 & 0.26 \\
\hline 3.2 & 1.21 & 4033.5 & 0.17 \\
\hline \multicolumn{4}{|l|}{ Change in mobile phase composition } \\
\hline Acetonitrile/buffer (45:55) & 1.35 & 4076.5 & 0.67 \\
\hline $\begin{array}{l}\text { Acetonitrile/buffer (40:60; optimized } \\
\text { condition) }\end{array}$ & 1.13 & 4097.1 & 0.29 \\
\hline Acetonitrile/buffer (35: 65) & 1.15 & 4087.6 & 0.24 \\
\hline \multicolumn{4}{|l|}{ Change in flow rate } \\
\hline $0.4 \mathrm{~mL}$ & 1.41 & 4010.4 & 0.75 \\
\hline 0.6 mL (Optimized condition) & 1.13 & 4097.1 & 0.38 \\
\hline $0.8 \mathrm{~mL}$ & 1.26 & 4088.9 & 0.56 \\
\hline \multicolumn{4}{|l|}{ Change in temperature } \\
\hline $30^{\circ} \mathrm{C}$ & 1.39 & 4038.4 & 0.63 \\
\hline $32^{\circ} \mathrm{C}$ (Optimized condition) & 1.13 & 4097.1 & 0.44 \\
\hline $34{ }^{\circ} \mathrm{C}$ & 1.18 & 4054.7 & 0.53 \\
\hline
\end{tabular}


Table 1 (continued)

\begin{tabular}{|c|c|c|c|c|}
\hline Initial amount $\left(\mu \mathrm{g} \mathrm{mL}^{-1}\right)$ & $\begin{array}{l}\text { Excess drug added to the } \\
\text { analyte (\%) }\end{array}$ & $\begin{array}{l}\text { Total amount found } \pm \text { SD } \\
\left(\mu \mathrm{gL}^{-1}\right)\end{array}$ & Recovery (\%) $(n=3)$ & $\% \operatorname{RSD}(n=3)$ \\
\hline \multicolumn{5}{|c|}{ Accuracy studies of mifepristone } \\
\hline 6 & 80 & $10.77 \pm 1.09$ & 99.45 & 1.09 \\
\hline 6 & 100 & $12.02 \pm 0.02$ & 100.28 & 0.29 \\
\hline 6 & 120 & $13.23 \pm 0.10$ & 100.35 & 1.35 \\
\hline
\end{tabular}

Table 2 Analysis of tablet formulation

\begin{tabular}{llll}
\hline Drug & $\begin{array}{l}\text { Amount taken } \\
\left(\boldsymbol{\mu} \mathbf{~ m L}^{-1}\right)\end{array}$ & $\begin{array}{l}\text { Amount found } \\
\left(\boldsymbol{\mu} \mathbf{~ m L}^{-1}\right)\end{array}$ & $\%$ amount found \\
\hline MFP & 9 & 8.95 & 99.41 \\
& 9 & 8.90 & 98.87 \\
9 & 9.00 & 99.96 \\
9 & 8.99 & 99.92 \\
9 & 8.97 & 99.62 \\
9 & 9.00 & 100.04 \\
& Mean \pm SD & $8.97 \pm 0.04$ & $99.64 \pm 0.44$ \\
& $\%$ RSD & 0.44 & 0.44 \\
\hline
\end{tabular}

Table 3 System suitability

\begin{tabular}{lll}
\hline Parameters & Standards & Results \\
\hline Retention time $\left(\mathrm{R}_{\mathrm{t}}\right)$ & - & 8.641 \\
Theoretical plates & More than 2000 & 4097 \\
Tailing factor & Less than 2 & 1.1 \\
Capacity factor & More than 2 & 2.4 \\
\hline
\end{tabular}

RSD lower than 2 indicates robust nature of developed method.

\section{System suitability}

System suitability parameter was determined by injecting $10 \mu \mathrm{g} \mathrm{mL}{ }^{-1}$ solution of mifepristone six times into column. The studies of system suitability included theoretical plate, tailing factor, capacity factor, and resolution. The data are given in Table 3.

\section{Forced degradation studies}

Forced degradation studies were performed by established RP-HPLC method on pure mifepristone to determine the stability and specificity of method. The pure mifepristone was subjected to various stress condition like acidic, basic, oxidative, dry heat, wet heat, and photolytic, but the degradation product of mifepristone was observed in all stress condition except in thermal and photolytic conditions. Mifepristone was well separated from all degradation products shown in Fig. 3.
The data found after forced degradation studies are depicted in Table 4.

\section{Discussion}

A new simple stability indicating method developed for determination of mifepristone in bulk and pharmaceutical formulation was found to be economical, precise, linear, and accurate. The analytical conditions were optimized for time saving analysis using acetonitrile: $10 \mathrm{mM}$ potassium dihydrogen ortho-phosphate 40:60 $\mathrm{v} / \mathrm{v}$ ratio as a mobile phase. The established solvent system was found to have very good symmetry with retention time $(8.67 \pm 0.02)$ and sharp well defined peak. The pure drug mifepristone was stable in the mixture of mobile phase for a period of $48 \mathrm{~h}$ at laboratory temperature and under refrigerator condition. The calculated \% RSD for precision was lower than 2 signify that the proposed RP-HPLC method was highly precise in nature. The \% recovery value in the range of $99-100 \%$ indicated that accuracy of the established RP-HPLC method was more satisfactory. The results of recovery studies were very close to $100 \%$ which accordance with $\mathrm{ICH}$ guidelines. Developed HPLC method was found to robust while small changing in $\mathrm{pH}$, flow rate, mobile phase, and temperature. The developed method with less retention time and good separation and can be applied for routine analysis of mifepristone in bulk and formulation. The result of ruggedness and robustness parameters shows results in accordance with $\mathrm{ICH}$ guidelines. From analyzed tablet formulation, the \% amount found and it shows that there is no interference of excipients present in tablet formulation. In stability study, it was found that drug degraded in acidic, basic and oxidative condition only and no degradant found in dry heat, wet heat and photolytic condition. The peak purity and peak of mifepristone obtained under all stress condition during forced degradation studies was pure, and homogeneous and mifepristone were well separated from all degradation products. It indicated that the developed method has stability indicating power and specific for the determination of mifepristone in bulk and pharmaceutical formulation. 

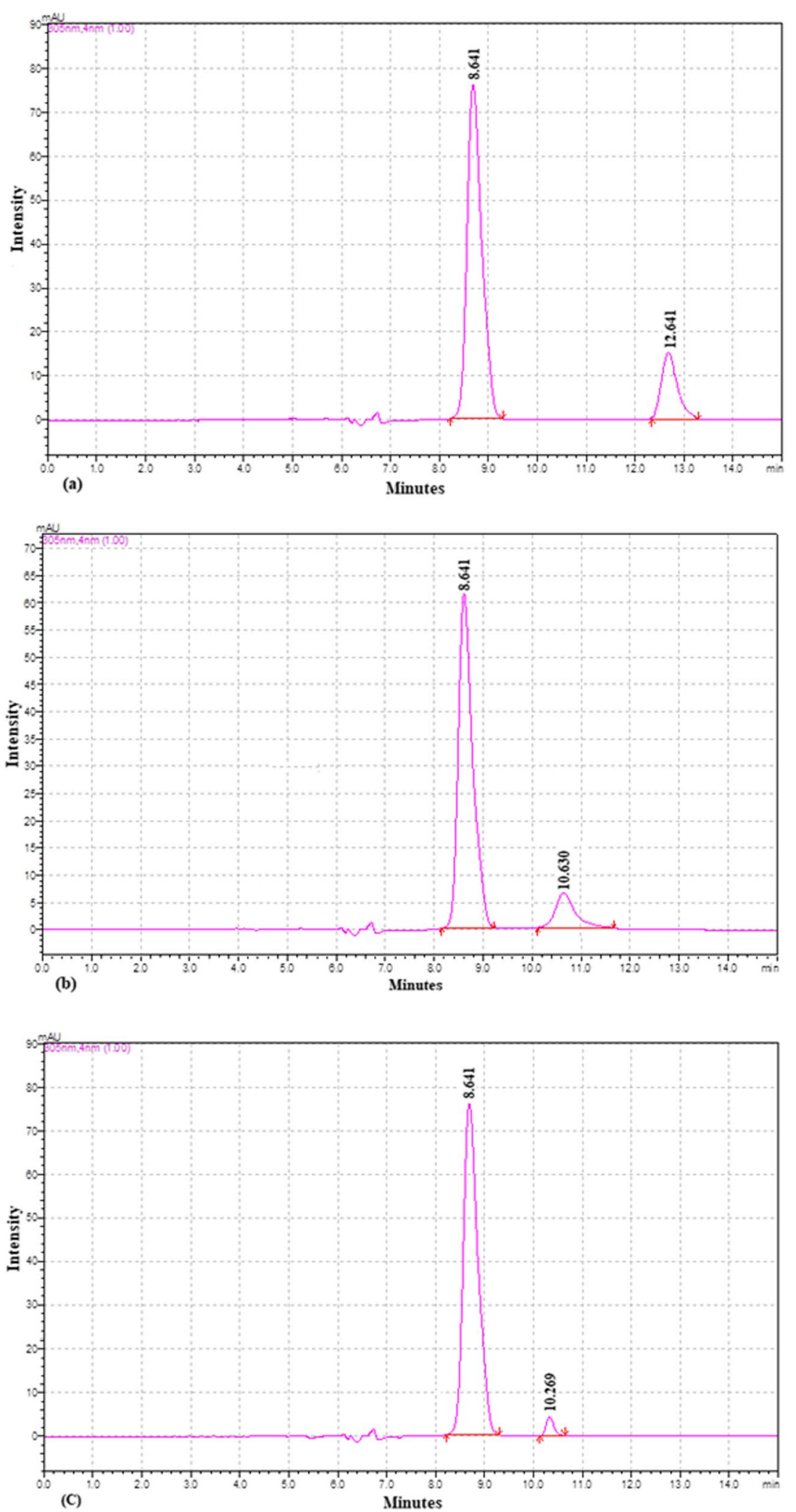

Fig. 3 Showing chromatogram of standard solution of mifepristone after forced degradation studies, a acidic hydrolysis $(0.1 \mathrm{~N}$ methanolic $\mathrm{HC}$ reflux at $70{ }^{\circ} \mathrm{C}$ for $3 \mathrm{~h}$ ), b alkali hydrolysis $\left(0.5 \mathrm{~N}\right.$ methanolic $\mathrm{NaOH}$ reflux at $70{ }^{\circ} \mathrm{C}$ for $5 \mathrm{~h}$ ), c oxidative degradation with $6 \% \mathrm{H}_{2} \mathrm{O}_{2}$ at room temperature for $8 \mathrm{~h}$ 
Table 4 Results of forced degradation studies

\begin{tabular}{llll}
\hline Degradation condition & Procedure & Observation & $\begin{array}{c}\% \\
\text { degradant } \\
\text { found }\end{array}$ \\
\hline Acid hydrolysis & $0.1 \mathrm{~N} \mathrm{Methanolic} \mathrm{HCl}$ reflux at $70{ }^{\circ} \mathrm{C}$ for $3 \mathrm{~h}$ & Degradant observed & 24.12 \\
Base hydrolysis & $0.5 \mathrm{~N} \mathrm{Methanolic} \mathrm{NaOH}$ reflux at $70{ }^{\circ} \mathrm{C}$ for $5 \mathrm{~h}$ & Degradant observed & 9.75 \\
Oxidative & $12 \% \mathrm{H}_{2} \mathrm{O}_{2}$ at room temperature for $8 \mathrm{~h}$ & Degradant observed & No degradant observed \\
Thermal (dry heat and wet heat) & Solution kept in hot air oven at $80{ }^{\circ} \mathrm{C}$ for $8 \mathrm{~h}$ & No degradant observed & - \\
Photolytic & Drug exposed to direct sunlight for 7 days & - \\
\hline
\end{tabular}

\section{Conclusion}

The RP-HPLC method was established and validated for the determination of mifepristone in bulk and tablet formulation. This method is simple, accurate, specific, precise, robust, rugged, sensitive and economical. Pure mifepristone peak was well separated from its degradation product; hence, it proves sensitivity of the method. The retention time for mifepristone is $8.67 \mathrm{~min}$ only, and total run time is $15 \mathrm{~min}$; hence, so many samples also be analyzed in short period of time. As per ICH guidelines, method was validated and showing satisfactory results for all the method validation parameters tested. Therefore, these established RP-HPLC method can be utilized for routine analysis of mifepristone in bulk and pharmaceutical formulation.

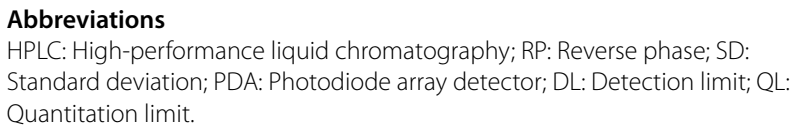

\section{Acknowledgements}

The authors are thankful to Dr. S. J. Surana, Principal of R.C. Patel Institute of Pharmaceutical Education and Research, Shirpur (M.S.), India, for providing the necessary facilities to carry out this research work.

\section{Authors' contributions}

MMGK, MF and AT completed the laboratory work, collected and analyzed the data and drafted the manuscript. SD, MGK and AS supervised the work and assisted in the data analysis. All authors read and approved the final manuscript.

\section{Funding}

Not applicable.

\section{Availability of data and materials}

Data and materials are available upon request.

\section{Declarations}

Ethics approval and consent to participate Not applicable.

\section{Consent for publication}

Not applicable.

\section{Competing interests}

The authors declare that they have no competing interests.

\section{Author details}

${ }^{1}$ Department of Pharmaceutical Chemistry, R.C. Patel Institute of Pharmaceutical Education and Research, Shirpur, Dist. Dhule, MS 425 405, India. ${ }^{2}$ Department of Pharmacognosy, R.C. Patel Institute of Pharmaceutical Education and Research, Shirpur, Dist. Dhule, MS 425 405, India.

Received: 2 July 2021 Accepted: 19 October 2021

Published online: 04 November 2021

\section{References}

1. The Merck Index (2006) An encyclopedia of chemicals, drugs, and biological, 14th edn. Merk \& Co., Inc, Whitehouse Station, p 129

2. Indian Pharmacopoeia (2014) Government of India Ministry of Health and Family Wealthfare. The Indian Phamacopoeial Commission, II, Ghaziabad, pp 1090-1094

3. http://www.drugbank.ca/drugs/DBO1609

4. Duan X, Ning M (2015) Development and in vitro/in vivo evaluation of a silastic intra vaginal ring for mifepristone delivery. Indian J Pharm Sci 77(3):335-342

5. Yamsani N, Shravani A, Prathima S (2016) Analytical method development and validation for the simultaneous estimation of mifepristone and misoprostol in bulk and pharmaceutical dosage form by RP-HPLC. Int J Chem Pharm Anal 3(1):1-10

6. Chen JZ, Wang JC, Gao Y, Zeng RJ, Jiang Z, Zhu YW, Shao JW, Jia L (2014) A novel UPLC/MS/MS method for rapid determination of metapristone in rat plasma, a new cancer metastasis chemopreventive agent derived from mifepristone (RU486). J Pharm Biomed Anal 95:158-163

7. Homer NZ, Reynolds RM, Mattsson C, Bailey MA, Walker BR, Andrew R (2009) Quantitative analysis of RU38486 (Mifepristone) by HPLC triple quadrupole mass spectrometry. J Chromatogr B 877(5-6):497-501

8. Tang C, Bi HC, Zhong GP, Chen X, Huang ZY, Huang M (2008) Simultaneous determination of mifepristone and monodemethyl-mifepristone in human plasma by liquid chromatography-tandem mass spectrometry method using levonorgestrel as an internal standard: application to a pharmacokinetic study. Biomed Chromatogr 23(1):71-80

9. Guo Z, Wang S, Wei D, Zhai J (2007) Development of a high-performance liquid chromatographic method for the determination of mifepristone in human plasma using norethisterone as an internal standard: application to pharmacokinetic study. Contraception 76(3):228-232

10. Guo Z, Wei D, Yin G, Wang S, Zhao S, Chu Y, Zhai J (2007) Simultaneous determination of rivanol and mifepristone in human plasma by A HPLC-UV method with solid-phase extraction. J Chromatogr B 856(1-2):312-317

11. Guo Z, Chu C, Yin G, He M, Fu K, Wu J (2006) An HPLC method for the determination of ng mifepristone in human plasma. J Chromatogr $B$ 832(2):181-184

12. Stith C, Hussain MD (2003) Determination of mifepristone levels in wild canid serum using liquid chromatography. J Chromatogr B 794(1):9-15

13. Chavan DD, Damle MC (2015) Development and validation of stability indicating HPTLC method for estimation of mifepristone. Int J Pharma Res Rev 4(4):13-19

14. Giri A, Saritha B, Reddy BV, Reddy TS (2014) Quantitative determination of mifepristone in pharmaceutical samples by, visible spectrophotometric 
method using Ce (IV) as an analytical reagent. Int J Pharm Sci Drug Res 6(3):246-249

15. Reddy KN, Giri A, Saritha B, Reddy V, Reddy TS (2017) Method development and validation of a visible spectrophotometric method for the assay of mifepristone in pharmaceuticial formulations using gold (lii). Int J Drug Res Technol 4(2):6

16. International Conference on Harmonization Guideline on Validation of Analytical Procedures (2005) Text and methodology: Q2 (R1).
17. International Conference on Harmonization Guideline on Stability Testing of New Drug Substances and Products (2003) Q1 A (R2).

\section{Publisher's Note}

Springer Nature remains neutral with regard to jurisdictional claims in published maps and institutional affiliations.

\section{Submit your manuscript to a SpringerOpen ${ }^{\odot}$ journal and benefit from:}

- Convenient online submission

- Rigorous peer review

- Open access: articles freely available online

- High visibility within the field

- Retaining the copyright to your article

Submit your next manuscript at $\boldsymbol{\nabla}$ springeropen.com 